\title{
LYGIA BOJUNGA E A LITERATURA INFANTO JUVENIL: UMA CRÍTICA LÚDICA E ABORDAGEM À REALIDADE SOCIAL
}

\author{
Sirlene Cristófano*
}

\begin{abstract}
Resumo: A relação entre literatura e sociedade é uma questão importante na tradição da crítica literária brasileira, portanto não podemos deixar de destacar a fundamental responsabilidade que essa relação exerce na organização da formação ideológica de uma sociedade: a literatura como um compromisso social. A escritora contemporânea Lygia Bojunga constrói as suas narrativas para o público jovem, sempre utilizando a infância como tema principal. Para além disto, as suas obras são caracterizadas por uma marcante infracção dos limites entre realidade e fantasia, repletas de simbologia, o que poderá proporcionar à criança um caminho para a maturidade $e$ para a busca da sua identidade. A escritora por meio de seus contos maravilhosos e realismo mágico eternizou estes valores, o que a tornou numa excelente representativa da literatura infanto-juvenil. Nas suas narrativas, repletas de agradáveis fantasias, que têm por fundamento elementos tomados do real, a autora debate os problemas sociais resultantes da ideologia dominante: a ditadura militar. Partindo deste ponto, este artigo pretende contextualizar Lygia Bojunga Nunes no seu tempo e no seu espaço literário, numa época política em que o Brasil vivia na ditadura, na qual a escritora empenhava-se na luta ideológica. $O$ presente trabalho tem por objetivo reflectir sobre um dos temas importantes de uma de suas narrativas, A Bolsa Amarela, que trata dos problemas existentes nas relações humanas e que faculta uma crítica contundente, por meio de vasta simbologia à realidade social.
\end{abstract}

Palavras-chave: Literatura Infanto-juvenil; Simologia; Conciencialização.

\section{Introdução:}

Ao falarmos da relação entre literatura e sociedade - questão importante na tradição da crítica literária brasileira - não podemos deixar de destacar a fundamental \footnotetext{
Porto, Portugal.

Mestre em Literatura, Culturais e Interartes, pela Faculdade de Letras da Universidade do Porto - FLUP -
} 
responsabilidade que essa relação exerce na organização da formação ideológica de uma sociedade. Podemos assim, pensar na literatura como um compromisso social.

Para tal, a escritora Lygia Bojunga constrói as suas narrativas maravilhosas utilizando a infância como tema principal. Para além disto, as suas obras são caracterizadas por uma marcante infração dos limites entre realidade e fantasia, repletas de simbologia, o que poderá proporcionar à criança um caminho para a maturidade e para a busca da sua identidade.

Conforme refere Jacqueline Held "dar à criança o gosto pelo conto e alimentá-la com narrações fantásticas, se escolhidas com discernimento, é acelerar essa maturação com manipulação flexível e lúcida da realidade real-imaginário" (HELD, 1980, p.53). A esse respeito, chamamos a atenção para o fato de que as mais antigas narrativas da humanidade são fantásticas e que, numa perspectiva teórica ou numa definição mais rigorosa deve ser chamada de "maravilhoso". Segundo Tzvetan Todorov, em As estruturas narrativas (1970), as narrativas fantásticas como género literário, surge no século XVIII, com Jacques Cazotte - com o romance O Diabo Apaixonado - são aquelas que exigem três condições: É necessário que o enredo exija do leitor a considerar o plano das personagens, como um mundo de pessoas vivas e hesitar entrem a explicação o natural e o sobrenatural dos fatos evocados; Essa hesitação deve ser sentida não só pelo leitor, mas também pelo personagem; O leitor deverá adoptar uma atitude em relação ao texto, recusando a interpretá-lo alegoricamente e também poeticamente.

O género fantástico nos remete a temas, com elementos sobrenaturais, como o incesto, o amor homossexual, o amor a vários, a necrofilia, a sensualidade excessiva, ou seja, uma infinidade de temas proibidos estabelecida pela censura e também que reina a psique dos autores. Podemos então, assim dizer que, fantástico é um meio de combate contra a censura.

Portanto, basta pensar nos mitos, nas epopéias e nos contos populares. Só muitos séculos depois é que a literatura passou a produzir um "realismo sério", ou seja, um texto verosímil, aquele que se semelha à verdade e teoricamente seria aquele que convence o leitor por sua fidelidade à natureza.

Quanto as narrativas maravilhosas sabemos que é uma categoria poética que tem a sua origem nos textos dos ritos mágicos. Todas as civilizações tiveram seus rituais mágicos que celebravam as crenças respectivas. Nelly Novaes Coelho (1987) vai ainda mais longe defendendo que os contos maravilhosos lidam com uma "temática social": o herói ou anti-herói, que é uma pessoa de origem humilde ou que passa por grandes privações, triunfa ao conquistar riqueza e poder.

Nas suas narrativas, repletas de agradáveis fantasias e simbologia, que têm por fundamento elementos tomados do real, as quais Tzvetan Todorov (1970) define o "fantástico maravilhoso", aquelas que de algumas ações não terem explicação ou razão, sugere-nos a existência do sobrenatural, ou seja, o limite entre os dois será o incerto; entretanto, a presença ou ausência de certos pormenores nos permitirá sempre decidir. Ao escrever tais narrativas, a autora debate os problemas sociais resultantes da ideologia dominante: a ditadura militar. No entanto, Lygia Bojunga não deixava de se preocupar com a função lúdica e seus livros sempre foram objetos de destaque no Brasil. 


\section{A Bolsa Amarela: Um compromisso social}

Em A Bolsa Amarela, o terceiro livro da autora, publicado em 1976,encontramos o ilusório sempre existente nas suas narrativas, e que aqui atinge perfeitamente o equilíbrio ideal entre a liberdade e as limitações do real.

O realismo mágico e a psicologia reúnem-se numa obsessão pelo social e pela democracia. A escritora, que iniciou a sua atividade quando ainda no Brasil vigorava a ditadura, foi uma ativista da resistência. Esta luta surge depois transposta para o domínio da literatura infantil, já que segundo a escritora, os generais não liam livros destinados a crianças e adolescentes. Em suas narrativas, encontramos personagens maravilhosas que se insurgem contra a desigualdade entre os sexos e também contra a diferença social. Porém, Lygia Bojunga nunca utiliza um discurso de admoestação, já que o importante é a tomada de consciencialização e esta sempre feita de uma maneira "maravilhosamente" bem-humorada.

Para a autora, o dia-a-dia, o quotidiano encontra-se repleto de encantamento de bom humor: onde despertam os desejos tão intensos que não são possíveis sustentá-los, onde personagens como alfinetes e guarda-chuvas dialogam tão convincentemente como os peões e as bolas, onde animais e objetos vivem vidas tão diversificadas e vulneráveis como as das pessoas.

Imperceptivelmente, o lado definido e preciso da realidade transforma-se num mundo imaginário através do mundo do real. E no interior da fantasia, que é o mundo da escrita, está a criança, muitas vezes só, sentindo-se abandonada, sempre emotiva, e cheia de fantasias.

Na obra, A Bolsa Amarela, a autora conta com humor a história de Raquel, uma menina muito atenta a tudo o que em passa a seu redor.

Lembrando o enredo: Raquel é a filha mais jovem da família, portanto a única que ainda é criança. Uma diferença de dez anos a separa dos seus irmãos, por isto eles não davam-na atenção. Eles consideram que as crianças não sabem grande coisa. Por se sentir muito só e oprimida, ela começa a escrever para os seus amigos: amigos imaginários, com os quais compartilhava três grandes desejos: ser um rapaz, crescer rapidamente e ser uma escritora.

Certo dia, Raquel ganhou uma bolsa amarela, que foi enviada num pacote oferecido pela tia Brunilda. E desta forma, a bolsa passou a ser o refúgio ideal das suas invenções e das suas vontades. Tudo se acomodava lá dentro. A bolsa amarela acaba por ser a casa de dois galos, de um guarda-chuva-mulher, de um alfinete de segurança e de muitos pensamentos e histórias inventadas pela criança.

Raquel, através das suas histórias conta-nos fatos do seu quotidiano, juntando o mundo real da família ao mundo criado pela sua imaginação, repleto de amigos secretos e de fantasias. 
Ao mesmo tempo, que acontecem fatos reais e fantásticos, uma aventura espiritual se processa, e a protagonista vai de encontro à sua afirmação como pessoa, pois no enredo, surge também a questão relacionada com o feminino e com a sua posição na sociedade, uma semelhança feita de estereótipos femininos. Logo na primeira página da narrativa de A Bolsa Amarela, a vontade da protagonista em ser um rapaz dá-nos o norte que seguidamente encontraremos ao longo do enredo. Esta vontade vem complementada de outros fortes desejos: a de crescer e deixar de ser criança, mas também o de ser uma escritora.

Mas, dos três desejos de Raquel, terão uma posição dominante e constante na narrativa de Bojunga: o de mulher/escritora e o da relação masculino/feminino. De fato, Raquel não se conforma em não poder desempenhar tarefas que só eram atribuídas aos rapazes e deseja, assim, libertar-se de um arquétipo de procedimentos que lhe foram imputados:

Se eu quero jogar uma pelada, que é o tipo do jogo que eu gosto, todo mundo faz pouco de mim e diz que é coisa pra homem; se eu quero soltar pipa, dizem logo a mesma coisa. É só a gente bobear e fica burra: todo mundo tá sempre dizendo que vocês têm que meter as caras no estudo, que vocês é que vão ser chefe de família, que vocês é que vão ter tudo. Até para resolver casamento - eu não te vejo - a gente fica esperando vocês decidirem (BOJUNGA, 1986, p. 16).

O discurso da protagonista vem de encontro às preocupações e ao debate das mulheres na década de setenta, quando o movimento hippie tendo por ideal idéias de Betty Friedman, luta pela igualdade entre os sexos, qualquer que fosse a sua raça, sexo ou cor. No entanto, no final da história, "a vontade de ser um menino emagreceu tanto que foi embora", o que prova que Raquel assumiu a sua identidade feminina e por isso, poderá crescer normalmente. Por outro lado também, a menina obtém graças à escrita a concretização que busca na vida real. O mundo da fantasia passa a ocupar um lugar importante na sua vida, pois a vontade de escrever é a única que prevalece, como podemos observar:

- E a tua vontade de crescer?

- Ah, essa eu não vou soltar. Mas, sabe? Ela agora não pesa mais nada: agora eu escrevo tudo que eu quero, ela não tem tempo de engordar (BOJUNGA, 1986, p.132).

Raquel reivindica deste modo, o seu direito à escrita e notamos que esta é também uma das questões levantadas pela escritora na narrativa. Naquela época, a mulher defrontava-se com a pesada herança do mito do escritor masculino. Em Escritora, Escritas, Escrituras, Norma Telles relata a dificuldade da mulher passar de poetisa a escritora, uma vez que esta função era atribuída aos homens. A mulher para se assumir, como escritora deveria "matar o anjo do lar, a doce criatura que segura o 
espelho de aumento, e teria que enfrentar a sombra, o lado do anjo, o monstro da rebeldia ou da desobediência" (TELLES, 2000, p. 408).

A protagonista ao mesmo tempo que adquire a sua identidade feminina acrescenta também o seu lado imaginativo e mostra que é possível ser mulher criadora, conseguindo libertar-se do papel insignificante destinado à mulher na escrita. Ainda neste contexto de identidade masculina/feminina existe outra personagem utilizada por Lygia Bojunga, em A Bolsa Amarela, para tratar este tema. De fato o galo Afonso é o conotado com a visão masculina, expressa na questão seguinte: se as mulheres possuem realmente vontade de ser donas de si próprias, ou seja, se são capazes de viver o seu próprio destino:

Então eu chamei minhas quinze galinhas e pedi, por favor, pra elas me ajudarem. Expliquei que vivia muito cansado de ter que mandar e desmandar nelas todas as noite e dia. Mas elas falaram. "Você é nosso dono. Você é que resolve tudo pra gente.» Sabe, Raquel, elas não botavam um ovo, não davam uma ciscadinha, não faziam coisa nenhuma, sem vir perguntar: «Eu posso?» $\mathrm{E}$ eu respondia: «Ora, minha filha, o ovo é seu, a vida é sua, resolve você como você achar melhor», elas desatavam a chorar, não queriam mais comer, emagreciam, até morriam. Elas achavam que era melhor ter dono mandado que ter que resolver qualquer coisa. Diziam que pensar dá muito trabalho (BOJUNGA, 1986, p. 35).

Esta problemática reflete, com alguma nitidez o contexto social da época e o lugar da mulher que não tinha sido instruída para os novos desafios que the eram colocados. Em A Bolsa Amarela, "Rei" é o nome do galo que não quer mandar e "Terrível" é o galo-de-briga que quer a paz. Aqui vemos exemplos que se seguem por toda a narrativa de Bojunga, que (te) matiza as questões de busca por uma marca própria, a discussão de uma direcção, a contestação dos papéis pré-estabelecidos, as injustiças cometidas contra os "diferentes".

Entre os autores contemporâneos que escrevem para crianças e jovens, a escritora Lygia Bojunga destaca-se por confirmar em toda a sua obra uma certa peculiaridade literária. Tal, as autoras Lygia Fagundes Telles, Cecília Meirelles, Rachel de Queiroz, Clarice Lispector, entre outras contemporâneas femininas, Lygia Bojunga Nunes encontra-se intensamente ligada à libertação da mulher e cuja mensagem vamos encontrar em A Bolsa Amarela, obra que sugestivamente nos remetem para o universo feminino. Deste modo, a sua narrativa enche-se de fantasias com a finalidade de discutir comportamentos sociais, frutos de convicções dominadoras.

A finalidade de Lygia Bojunga discutir em sua narrativa tais comportamentos sociais é a de proporcionar ao leitor "o conhecimento do mundo" e também o "conhecimento do seu próprio ser". Podemos dizer que em sua narrativa encontramos a função humanizadora, a qual permite representar, cognitiva ou sugestivamente, a realidade social e também a fantasia.

A conjunção entre fantasia e realidade contidas em A Bolsa Amarela constroem um mundo coerente, racional, e, simultaneamente alimentam-se da fantasia e do 
imaginário de Lygia Bojunga, por meio de uma sucessão de símbolos. De acordo com Gilbert Durand, em A Imaginação Simbólica (1993), "símbolo é uma representação que faz parecer um sentido concreto, é a epifania de um mistério" (DURAN, 1993, p.12).

Desta forma, concilia a racionalidade da linguagem com a ficção, onde ao mesmo tempo que rege a criação imaginária, não se afasta do contato com a realidade. Devido à esta característica ambivalente, a narrativa provoca um efeito também duplo no leitor: aciona sua imaginação e fantasia e desencadeia uma posição intelectual.

$\mathrm{Na}$ medida em que atua tanto no âmbito individual, como no social: no social transporta-o para um mundo que, por mais longe que esteja do quotidiano, leva-o a refletir e a enriquecer a sua vivencia e a sua experiência. Já no âmbito social permite que o leitor socialize a sua experiência de leitura, compartilhando-a com outros leitores, para a troca de idéias e opiniões.

A Bolsa Amarela, repleta de simbologias é utilizada como dispositivo para o despertar e o contristar da consciência, para a expansão da capacidade e interesse de analisar o mundo, pois de acordo com Paul Ricouer, na afirmação de Maria Antónia Jardim, "o ato de leitura contribui para uma dialética entre o mundo do texto e o texto do leitor e a compreensão de si mesmo [...] dado que a compreensão de si é a narrativa, pois compreender-se corresponderá à apropriação da história da nossa própria vida (JARDIM, 2003, p. 218).

Na narrativa maravilhosa, o símbolo poderá ser, por exemplo, uma personagem, que irá enriquecer a identidade da criança, porque com ela esta aprender outras formas de ser e de pensar.

Os símbolos encontrados em A Bolsa Amarela possibilitam ampliar as concepções sobre o meio, pois, através do imaginário, a criança desenvolve e vivência diversos papéis sociais, aprendendo com cada um deles e podendo, assim, reproduzir o que encontra na leitura.

Conscientes da importância dos símbolos não poderemos, nunca, estudá-los de forma descontextualizada, mas antes, como escrevíamos anteriormente, tendo sempre presente a especificidade do imaginário da personagem feminina, em A Bolsa Amarela, obra de Lygia Bojunga.

Portanto, sempre que assimilamos o símbolo devemos ter cuidado em analisá-lo isoladamente, pois concordando com o autor Jean-Michel Adam (1997), este só existe no plano do sujeito, mas tendo base o plano do objeto podendo, como anteriormente mencionávamos, ganhar contornos e variações em extensos números campos do saber.

\section{Elementos Simbólicos em A Bolsa Amarela: O dispositivo para o despertar e contristar da consciência}


Relembrando as palavras de Mircea Eliade (2002) quando escreve que, as imagens, os mitos e os símbolos estão ligados às mais secretas modalidades do ser, procederemos ao levantamento e análise de «alguns» símbolos na A Bolsa Amarela, de Lygia Bojunga Nunes.

Os desejos de Raquel, que se manifestam através da criação de figuras ou comportamentos e ações revelam os seus desejos, os seus conflitos, etc. É importante ressaltarmos que os mecanismos de "brincadeira" que Raquel pratica através das suas fantasias e da sua imaginação são comparáveis ao "sonho diurno». Freud dá este nome a um enredo imaginado no estado de vigília, sublinhando assim, a analogia que une estes dois componentes. Para Jones Laplance, nas palavras de Freud, "os sonhos diurnos constituem, como o sonho noturno, realizações de desejo; os seus mecanismos de formação são idênticos, com o predomínio da elaboração secundária" (FREUD, 1996, p.634)

A fantasia ou devaneio é de grande importância, pois Freud, por meio de suas pesquisas verificou que os devaneios partilham também com os sonhos noturnos, várias características essenciais. Para o pesquisador, "tal como os sonhos são realizações de desejo; [...] tal como os sonhos beneficiam para as suas criações de uma certa indulgência por parte da censura [...] relativamente às recordações de infância a que se referem [...] (LAPLANCE, 1996, p.635).

As fantasias diurnas de Raquel partilham com o sonho noturno alguns elementos importantes. De acordo com Freud os devaneios podem, de forma mais específica, fornecer à elaboração secundária em enredo completamente montado, a «fachada do sonho», como nos mostra o texto de A Bolsa Amarela:

[...] Uma noite eu sonhei que estava na praia soltando pipa. Acordei e falei pró Afonso:

- Sabe? Disseram que eu não podia soltar pipa.

- Por quê?

- Falaram que era coisa de garoto.

- Ué!

- Tá vendo? Falaram que tanta coisa era coisa pra garoto, que eu acabei até pensando que o jeito era mesmo nascer garoto. Mas agora eu sei que o jeito é outro. Vamos lá pra praia soltar pipa? (BOJUNGA, 1976, p.126)

O fantasma ou fantasia está em estreita relação com o desejo que Raquel sublima graças à escrita. Freud recorre à noção de sublimação - termo este introduzido pelo referido autor - para tentar explicar algumas atividades alimentadas por um desejo que não visa, de forma manifesta, um alvo sexual e que é capaz de dar origem a outro alvo socialmente valorizado.

O sonho está repleto de simbolismo tal como a criação literária. Em Lygia Bojunga, o próprio título, A Bolsa Amarela, é já um elemento importante neste domínio. 
Propomo-nos expor algumas dessas simbologias que nos ajudarão a perceber o universo metafórico do conto.

O "nome" e as "vontades" da protagonista: Logo no início deparamo-nos com a narradora e, ao mesmo tempo, protagonista Raquel, que, através de uma confissão vai revelando alguns problemas com os quais se debate: [...] Eu tenho de encontrar um lugar para esconder minhas vontades [...] (BOJUNGA, 1976, p.11.)

Repare-se, desde logo, que o nome Raquel, de origem hebraica, significa "calma como ovelha" mas, ao mesmo tempo, encerra igualmente o significado de alguém que frequentemente, sente-se vítima de uma situação familiar ou social. Na escolha do nome próprio da protagonista já se revela, assim, a intenção da escritora. O nome Raquel insinua já sentimentos de vítima e de revolta, sentimentos assumidos pela heroína ao longo da narrativa.

“As vontades", de ser garoto, de crescer e de ser escritora são vontades "que vão crescendo e engordando", e que geram conflitos entre a protagonista e a sua família. A Raquel não é dada voz em casa, não possui direitos de escolher ou de discordar. Podemos dizer que, por ser ainda uma criança, os seus desejos ou "vontades" são desvalorizados pelos seus pais e irmãos e, portanto, encontramos aqui, simbolicamente representada, a ideologia de uma sociedade que se recusa a encarar a criança como um ser dialogante, com problemas específicos e próprios da idade, com seus dramas, seus ideais e seus devaneios. Não podemos relegar que a narrativa, publicada em 1976, época da ditadura, aparece como uma crítica à sociedade. Essa crítica foi realizada num conto infantil, porque segundo Lygia Bojunga, os generais não liam livros infanto-juvenis.

A partir destas vontades gera-se, portanto, um ciclo fascinante de invenção, de jogo entre o real e o imaginário. Essa especificidade de uma mente que mistura o real e a fantasia justifica o uso de uma linguagem e que metafórica, mistura o lúdico e o maravilhoso. Uma das mais fortes vontades de Raquel prende-se com o interesse pela profissão de escritora. E sabe-se que escrever e inventar revela uma fuga à realidade que se vive.

A "viagem" e o "quintal": Raquel, numa carta dirigida a uma outra amiga imaginária, "Lorelai", diz estar decidida a fugir com ela, para o quintal, local onde "o pessoal anda de mão dada, não tem briga, não tem cara amarrada, e ainda por cima, tem gato, rio, galinheiro" (BOJUNGA, 1976, p.19). O "quintal" representa, deste modo, o espaço simples, atraente e aberto aos elementos que representam uma infância feliz. Este espaço não é só o "pequeno mundo" de Raquel, mas também o ponto de referência e o regresso aos momentos felizes e o seu refúgio contra a incompreensão e a repressão.

Perante estas situações, Raquel inventou uma "viagem" ou fuga para o quintal com Lorerai. De acordo com Jean Chevalier e Alain Cheerbrant, o simbolismo da viagem resume-se na busca da verdade. Os respectivos autores em Dicionário dos Símbolos, afirma que "em todas as literaturas, a viagem simboliza, portanto, uma aventura e uma procura, quer se trate de um tesouro ou de um simples conhecimento, concreto ou espiritual" (CHEVALIER e GHEERBRANT, 2002, p.952). Afirmam ainda que essa procura, no fundo não passa de uma busca e na maioria dos casos uma fuga de si mesmo. 
A protagonista encontrará assim, através da feitura de um romance, uma alternativa para a sua "viagem" com destino à imaginação. Graças à escrita, ela sente-se livre para criar seus amigos, suas estórias e viver a sua própria aventura, porque segundo Raquel, "ninguém mais vai poder ficar contra mim, porque todo mundo sabe que romance é coisa mais inventada do mundo" (BOJUNGA, 1976, p.20). E a partir deste instante, a vontade da protagonista em ser escritora, desatou a engordar como as outras duas vontades.

Sobre a simbologia do "galo": Raquel, ao partir para a "sua viagem imaginária" decide, então, escrever a história de um galo que foge do galinheiro por estar revoltado contra as normas que aí imperam. O galo, segundo CHEVALIER e GHEERBRANT (2006) é conhecido como o emblema da altivez, arrogância, do orgulho, da soberba.

Para os autores, o galo é "símbolo da luz nascente [...] é ao mesmo tempo, o signo da vigilância e o do advento da luz iniciática" (CHEVALIER e GHEERBRANT, 2002, p.458 e 459).

Não é por acaso que a protagonista insere um galo nas suas histórias. Nesta figura encontramos, para além da auto-identificação de Raquel com o elemento masculino, essa outra faceta que Raquel perfilha: a situação de revolta e a busca pela liberdade. De fato, também o galo se sente sufocado pelas regras que lhe são impostas.

Lygia Bojunga, através da simbologia desta personagem, mostra-nos que Raquel busca conhecer-se a si mesma através da fantasia. Assim, como o galo considerava todas as galinhas do galinheiro esquisitas e resolve portanto, fugir, também Raquel, por considerar o mesmo de sua família, resolve fugir da realidade.

Podemos notar através da imagem "evocativo" do galinheiro, a valorização da hierarquia, pois o galo encontra-se numa posição de superioridade em relação às galinhas que com ele coabitam no mesmo espaço físico o que certamente, corresponde também à posição de superioridade do homem à mulher.

Raquel se vê simbolicamente na figura do galo, pois esta personagem problematiza a mudança nos poderes. Raquel tal como o galo (que tem poder no galinheiro) conseguem solucionar o seu complexo de inferioridade e submissão em relação à sua família, à sociedade e às suas respectivas regras.

Mas as histórias da protagonista são descobertas pela família e, mais uma vez, censuradas. Questionada pelos seus pais, estes fazem com que a fuga imaginária que lhe trouxe alívio perca a sua validade. É neste momento da narrativa que surge a bolsa amarela, apresentada como um objeto mágico e secreto e passa a ser vista por Raquel como uma oportunidade para esconder os seus amigos os imaginários e as suas vontades.

Simbologia da bolsa amarela: Um dado curioso é que, ao ver o desenho na capa da obra, pensamos que a narrativa tratará especificamente de uma bolsa ou então que ela desempenhará o papel principal no conto. De fato, o objeto bolsa, é dotado de um importante papel.

Podemos relacionar a simbologia da bolsa de Raquel, com a bolsa d'água, pois, assim tal como esta exerce a função de protetora, ao pensarmos no invólucro de líquido amniótico, que apresenta-se como um signo de ventura, de boa sorte para o recém- 
nascido, segundo Jean CHEVALIER, e Alain GHEERBRANT (2006). Portanto, da mesma maneira, pode entender-se que a bolsa da Raquel dá a esta, a segurança e o refúgio para todos os desejos mais secretos. Contudo, a bolsa amarela apresenta-se como um símbolo, um talismã de felicidade para a Raquel.

A bolsa da personagem é como um ventre materno, lugar de refúgio, de proteção e de transformação. A bolsa amarela dá a protagonista a possibilidade de proteger os seus sonhos e desejos e, ao mesmo tempo, é o local onde as suas vontades reprimidas serão transformadas em descobertas e auto valorização de seus sentimentos. De acordo com Jean CHEVALIER, e Alain GHEERBRANT, o ventre é "símbolo da mãe [...] reflectindo particularmente uma necessidade de ternura e de protecção [...] Local das transformações [...] $\mathrm{O}$ calor do ventre facilita as transformações [...] O ventre é refúgio” (CHEVALIER e GHEERBRANT, 2002, p.937).

A bolsa representa, sem dúvida, o interior da personagem, lugar onde a protagonista guarda e esconde os seus desejos e os seus segredos, protegendo-os da interferência dos adultos que se recusam a compreendê-la.

A bolsa detém também uma importante e especial simbologia: a da mulher forte, estabelecida na sociedade, papel que inconscientemente, Raquel deseja assumir. Ainda podemos ressaltar que a cor da bolsa, amarela, também evoca outros sentidos que a própria narradora acentua, ao afirmar que "amarelo é a cor mais bonita que existe. Mas não [...] um amarelo sempre igual: às vezes [...] forte, mas depois ficava fraco [...] já resolvendo que ser sempre igual é muito chato” (BOJUNGA, 1976, p.27).

Metaforicamente, a cor amarela representa a mutação que a menina está vivendo. Ainda segundo Jean Chevalier e Alain Gheerbrant, a cor amarela é: "[...] a mais ardente das cores, difícil de atenuar e que extravasa sempre dos limites [...] está associada ao mistério da Renovação" (CHEVALIER e GHEERBRANT, 2002, p.40). Ou seja, a bolsa de cor amarela mantém uma relação simbólica com o interior de Raquel. Nela, a heroína procura força e autonomia para as suas vontades, para enfrentar as reprovações da família e a censura da sociedade, além de também representar o seu amadurecimento.

Simbologia do "galo Rei" e do nome "Afonso": Por não aguentar as imposições de seus donos, o galo foge do galinheiro e ao fugir, refugia-se na bolsa amarela. Aí é batizado por Raquel com o nome de Rei. Porém ele recusa-o, já que no imaginário infantil, não existe ainda o sentido das hierarquias sociais. Ora, é isso que a figura do rei representa. De fato, para a criança todos são iguais, logo, todos têm os mesmos direito.

O rei é simbolicamente, como uma projeção do "eu" superior, o ideal a realizar, e ainda, "torna-se um valor ético e psicológico. Sua imagem concentra sobre si os desejos de autonomia, de governo de si mesmo, de conhecimento integral, da consciência [...]" (CHEVALIER e GHEERBRANT, 2002, p.776).

O galo, nesta narrativa é, justamente, portador de um papel dialéctico: este ser "dominado" pelos seus donos tem, concomitantemente, como função de "dominar" o galinheiro. Por isso, a personagem não sendo capaz de conviver com as antinomias e de pactuar com um regime ditatorial resolveu afirmar-se e cedendo aos seus impulsos de liberdade e de não sujeição, realizou o seu ideal. 
Na opinião de Marie Louise Von Franz (1978), num conto infantil, a figura de um rei incarna a dominante do consciente coletivo, a imagem central que rege a coletividade.

O galo passa, então, a chamar-se Afonso, outro nome masculino, o que acomoda a vontade da protagonista em ser homem. O nome Afonso, de origem teotónica, significa "guerreiro preparado" o que simboliza "pronto para combate" e preocupado com o bem-estar dos outros, procurando ajudar todos os que se encontram em dificuldades. Está no fundo, mostrando ser um idealista que coloca a justiça acima de tudo.

O nome Afonso veicula uma mensagem. Ele é o galo que, ao fugir do galinheiro, leva consigo a ambição de lutar pelas suas idéias e pelos seus ideais. Este fato deve ser relacionado com o momento que Raquel vive relativamente à sua transformação, ou seja, as tais ambições da personagem galo são na realidade, os questionamentos e os valores em que Raquel acredita.

Sobre "o alfinete" e o "guarda-chuva": Certa vez, Raquel encontra na rua perdido um pequeno alfinete de fralda. Não podemos deixar de relacionar este pequeno objeto com o espírito da infância, ou seja, tudo aquilo que é mais ingénuo e infantil em Raquel. O "alfinete de fralda" perdido e largado na rua, simboliza também, em nosso entender, todas as infâncias esquecidas, as crianças abandonadas e a injustiça social de que são alvo. De todos os amigos imaginários de Raquel, o único que a protagonista guardará é o alfinete, para que um dia, mesmo quando for adulta, encontre a sua natureza pura e infantil.

No capítulo "A volta da escola" nos é apresentado um outro personagem, um guarda-chuva que Afonso encontra e com o qual vai presentear Raquel. Esta personagem alude aos elementos femininos utilizados por Lygia Bojunga na sua narrativa. O objeto apelidado por Raquel de "A guarda-chuva" reenvia-nos para uma concordância entre a protagonista e o seu sexo. A além disto, atua como um abrigo, uma proteção, ou seja, uma segurança que a menina está ganhando.

Segundo Jean Chevalier e Alaine Gheerbrant, a simbologia do guarda-chuva, pode desempenhar a função "do acolhimento, da protecção [...] Simbolicamente é uma fuga das realidades e das responsabilidades" (CHEVALIER e GHEERBRANT, 2002, p.480).

À estrutura, ou seja, a mecânica do guarda-chuva também corresponde uma simbologia: a menina compreenderá que não tardará a transformar-se na adulta que idealiza ser e que ao tornar-se mulher (e não o homem que desejara ser) também terá condições de ser tão forte e independente, como qualquer pessoa do sexo masculino. Mas independente do que almeja ser, inconscientemente, continuará sempre, a ter sempre a essência pura e infantil de agora.

Outra personagem que arrasta consigo também uma simbologia na narrativa, é o galo de briga, de seu nome Terrível, primo do galo Afonso. Terrível, cujo pensamento foi costurado por uma Linha Forte, ganha também ele, um significado muito importante, dada a sua relação com o poder.

O galo Terrível, que foi ensinado a detestar e a não aceitar derrotas, tem somente um pensamento único, livre e "descosturado": "pensar em brigar e ganhar de todos os 
seus adversários". Julgamos estarem aqui expressas algumas das críticas de Lygia Bojunga à sociedade do seu tempo, pois, no universo capitalista, o que importa mesmo, é ganhar sempre, é "o lucro". O galo de briga preocupa-se exclusivamente com os lucros e ganhos para o seu dono, da mesma forma que a classe trabalhadora representa "o ganho", "o lucro" para a classe empresarial, em troca de um pequeno salário.

A autora utiliza a personagem Terrível, que pelo seu pensamento costurado é a metáfora do cidadão médio, escravizado por um sistema que controla o pensamento.

A Linha Forte que costura os pensamentos do Terrível é na realidade, uma analogia à "linha dura" do regime totalitário. Simbolicamente ele representa o regime militar, ou seja, a conjuntura política brasileira, em 1976, ano em que a obra foi publicada. Eis aqui o mérito da obra de Lygia Bojunga, pois, dificilmente uma outra obra conseguiria utilizar metáforas tão criativas para denunciar os processos da ditadura. Segundo Chevalier e Gheerbrant (2006), a linha retilínea tornou-se o símbolo ou o traçado da rigidez intelectual e moral.

Sobre a simbologia do "sonho" e do"mar": No regresso às aulas, Raquel sentiase melhor com as suas vontades já mais magras, dando a impressão que iriam sumir-se. A protagonista percebia que a sua vida estava a melhorar. Ora, ela teve um sonho. Sonhou que estava na praia soltando pipas. Refira-se que "o sonho é a expressão ou realização, de um desejo reprimido [...] é a auto-representação, espontânea e simbólica, da situação actual do inconsciente" (CHEVALIER e GHEERBRANT, 2002, p.843).

Podemos afirmar que o sonho é um dos melhores agentes de informação sobre o estado psíquico de quem sonha. Raquel, ao sonhar, revela-nos um quadro da sua situação existente e presente, visto o sonho ser para quem sonha, uma imagem frequentemente insuspeitada de si mesmo e é segundo Chevalier e Gheerbrant (2006), um revelador do ego e do self.

Raquel regressa, através do sonho, para a praia e fica olhando para o mar. Afonso abria as asas para voar bem alto. As asas, símbolos do levantar voo, do aligeirar de um peso, de desmaterialização e de liberação, remetem para a idéia da autoconfiança conquistada por Raquel, graças à personagem Afonso. De acordo com Jean Chevalier e Alain Gheerbrant, as asas "exprimem geralmente uma elevação ao sublime, um impulso para transcender a condição humana [...] indicam uma liberação e vitória" (CHEVALIER e GHEERBRANT, 2002, p.90).

Quanto ao vento, nele podemos reconhecer vários atributos. Deste modo, ele revela-se como "símbolo da vaidade, de instabilidade, de inconstância Quando o vento aparece nos sonhos, anuncia que um evento importante está para acontecer; uma mudança surgirá" (CHEVALIER e GHEERBRANT, 2002, p.935). A mudança sugerida pelo símbolo do vento é a transformação que Raquel sofrerá a partir do universo criado e graças ao seu poder imaginativo. Mudança esta, referida na voz da personagem Afonso, ao reconhecer que não precisava mais ter medo de voar alto e que chegara a hora de sair pelo mundo lutando por sua ideia.

Já o ato de sonhar com o mar sugere uma transformação, pois o mar tem por símbolo, a dinâmica da vida, pois 
Tudo sai do mar e tudo retorna a ele: lugar dos nascimentos, das transformações e dos renascimentos. Água em movimento, o mar simboliza um estado transitório entre as possibilidades ainda informes as realidades configuradas, uma situação de ambivalência, que é a de incerteza, de dúvida, de indecisão (CHEVALIER e GHEERBRANT, 2002, p.592).

Concordando com Jean Chevalier e Alain Gheerbrant (2006) dizemos que o sonho permitiu estabelecer no psiquismo da protagonista uma espécie de equilíbrio compensador, pois como se sabe, o sonho acelera o processo de individualização que rege a evolução de ascensão e da integração do homem. Assim, podemos exemplificar por meio da fala da protagonista:

Então entrei no mar de uniforme, sapato, bolsa amarela e tudo. Furei uma onda e mergulhei fundo $[\ldots]$ pela primeira vez na minha vida, achei Raquel um nome legal. Achei que não precisava de outro nome nenhum. Abri a bolsa, tirei tudo quanto é nome que eu guardava no bolso sanfona [...] eu tive que sair do mar [...] agora eu escrevo tudo o que quero ela [a vontade] não tem tempo de engordar [...] A bolsa amarela tava tão vazia [...] E eu também, gozado, eu também estava me sentindo um bocado leve" (BOJUNGA, 1976, p.115).

Raquel transformou-se, a partir do mundo que criou e que os seus devaneios e a sua imaginação permitiram. A protagonista encontrou-se e compreendeu-se como criança. Sentindo-se feliz consigo própria, encontrou a sua verdadeira natureza e identidade. Não necessitava mais das duas vontades dominantes e obsessivas: a de ser um homem e a de ser um adulto.

A única vontade que guardou consigo foi a de ser escritora, pois, assim, continuaria a construir os seus mundos, os seus amigos, os seus sonhos, independentemente da idade que tivesse. Poderia cumprir uma importante função social como escritora de contos maravilhosos: denunciar a opressão, a exclusão, o preconceito e também mostrar as normais diferenças existentes entre as pessoas, contribuindo assim, para a inclusão social.

\section{Conclusão}

O domínio descritivo de Lygia Bojunga, o qual manifesta-se a partir da infância, abrange temas adultos com os relatos de poder e rejeição e com a liberdade de manifestação em contexto social. A autora dá argumentos ao leitor/criança para se identificar com as condições que dizem à respeito as personagens infantis, criando-lhe uma identificação com os fatos, por meio de vasta simbologia, de forma a prender-lhe a atenção e desperta-lhe a sua fantasia e curiosidade. 
A Bolsa Amarela permite o enriquecimento da vida do pequeno leitor ao estimular-lhe a imaginação, pois segundo Bruno Bettelheim (2006), para que uma história possa verdadeiramente prender a atenção do jovem leitor e para também lhe enriquecer a sua personalidade, tem de estimular a sua imaginação; tem de ajudá-la a desenvolver o seu intelecto e esclarecer as suas emoções; tem de estar sintonizadas às suas angústias e as suas aspirações.

É a partir da história de Raquel, uma garota que entra em conflito consigo mesma e com a família ao reprimir as suas vontades, que se enquadra a oposição à estrutura familiar ancestral. E essa menina, afetiva e sonhadora, conta-nos o seu dia-a-dia, onde o mundo real e mundo criado pela sua imaginação criativa, povoado de amigos ocultos e fantasistas, se interligam ao mesmo tempo que os fatos reais e os fantásticos cruzandose numa aventura anímica e mais íntima. É Raquel que segue rumo à sua auto-afirmação como pessoa.

Assim, A Bolsa Amarela prefigura e sugere uma postura de submissão da criança face às regras impostas pelos adultos, Raquel é de certa forma um joguete, objeto infantil nas mãos dos seus familiares, por isso, vai controlando os seus desejos dentro da bolsa. Neste momento da narrativa, os pré-julgamentos contra as crianças e a mulher impostos pelos adultos vão sendo contraditos e questionados pela protagonista e evidencia-se através da sua leitura que a imagem feminina se revela sob vários aspectos. A autora deixa à criança leitora a hipótese de construir a sua imagem e não pretende impor-lhe a possibilidade um único perfil.

Defendendo a idéia do conto maravilhoso como trampolim para o autoconhecimento, procuramos captar em A Bolsa Amarela, uma espécie de espelho mágico capaz de operar como uma imagem fiel do universo dos valores infantis.

Na verdade, os contos maravilhosos, são registos simbólicos, através dos quais a psique se manifesta podendo assim contribuir para a formação harmoniosa do leitor, seja ele criança ou jovem. O texto literário, especificamente o conto maravilhoso, segundo Bruno Bettelheim (2006), favorece o desenvolvimento psíquico e a compreensão dos conflitos existentes no leitor, graças aos elementos presentes, que promovem imagens com as quais ele pode estruturar seus devaneios e com estes dar melhor orientação à sua vida.

Em suma, a narrativa de Lygia Bojunga, por meio de uma crítica lúdica e abordagem a realidade social, reveste de grande utilidade ao abrir pistas de reflexão sobre o papel do ser humano na sociedade, e apela a cada leitor para que tome consciência da sua identidade própria, para que este escolha o caminho correto sem olhar as diferenças, sem preconceitos e sem discriminação.

\section{Referências Bibliográficas}

ADAM, Jean-Michel. Le style dans la langue: une reconception de la stylistique. Lausanne, Delachaux \& Niestlé, 1997. 
BETTELheIN, Bruno. A psicanálise dos Contos de fadas. Lisboa: Editora Bertrand, 2006.

BOJUNGA, Lygia. A Bolsa Amarela. Rio de Janeiro: AGIR Editora, 1976.

COELHO, Nelly Novaes. O Conto de Fadas. São Paulo, Ática, 1987. Disponível em: «http://pt.wikipedia.org/wiki/Contos_maravilhosos» acesso em: 10 set 2009.

CHEVAliER, Jean, e GHEERbRANT, Alain. Dicionário dos Simbolos. $17^{\mathrm{a}}$ ed. Rio de Janeiro, José Olympio, 2002.

DURAN, Gilbert. A Imaginação Simbólica. Lisboa, Edições 70, 1993.

ELIADE, Mircea. Imagens e Símbolos - Ensaio sobre o Simbolismo MágicoReligioso. São Paulo, Martins Fontes, 2002.

FRANZ, Marie Louise Von. La Voie de L'Individuation dans les Contes de Fées. Paris, La Fontaine de Pierre, 1978.

FREUD, Sigmund. O estranho. In: Edição Standard das Obras Psicológicas Completas de Sigmund Freud - 24 Volumes, Rio de Janeiro, Imago, 1996.

HELD, Jacqueline. O imaginário do poder: as crianças e a literatura fantástica. São Paulo: Sumus, 1980.

JARDIM, Maria Antónia. Da Hermenêutica à Ética em Paul Ricoeur. Porto: Universidade Fernando Pessoa, 2003.

LAPLANCE, Jones, Vocabulário da Psicanálise, Lisboa, Moraes Editores, 1970.

TELLES, Norma. História das Mulheres no Brasil. São Paulo: Contexto, 2000.

TODOROV, Tzvetan. As estruturas narrativas. São Paulo, Ed. Perspectiva, 1970.

\title{
Webgrafia:
}

«http://www.significado.origem.nom.br/nomes_a/». Acesso em: 10 set 2009.

\begin{abstract}
The relationship between literature and society is an important issue in the tradition of literary criticism in Brazil, so we can not fail to highlight the fundamental relevance that this relationship has in the organization of the ideological formation of a society: literature as social commitment. A contemporary writer, Lygia Bojunga builds her narratives for young people, always using the child as the main theme. In addition, her works are characterized by a marked the defiance of the boundaries between reality and fantasy, which may give children a way to maturity and the search for their identity. The author, through her wonderful tales and magical realism, has immortalized these values, which turned her into an excellent representative of children's literature. In her narratives, full of pleasant fantasies, which have as their basis elements taken from real life, the author discusses the social problems resulting from the dominant ideology: the military dictatorship. From
\end{abstract}


this point, this article aims to contextualize Lygia Bojunga Nunes in her time and her literary space in a political season when Brazil lived under a dictatorship, in which the writer was engaged in the ideological struggle. This paper aims to reflect on an important topic of one of her stories, A Bolsa Amarela, which deals with problems in human relations and offers a scathing critique of social reality.

Keywords: Children's literature; Symbology; Awareness. 